\title{
Cytotoxicity of herbal extracts used for treatment of prostatic disease on head and neck carcinoma cell lines and non-malignant primary mucosal cells
}

\author{
MARIANNE SCHMIDT, CHRISTINE POLEDNIK, JEANETTE ROLLER and RUDOLF HAGEN
}

Department of Otorhinolaryngology, University of Wuerzburg, D-97080 Würzburg, Germany

Received August 3, 2012; Accepted September 18, 2012

DOI: $10.3892 / o r .2012 .2145$

\begin{abstract}
Previously, a growth inhibiting effect of PC-Spes on head and neck carcinoma cell lines had been demonstrated. In order to determine the toxic impact of particular herbs in the mixture, we exposed the head and neck cancer cell lines FADU, HLaC79 and its Paclitaxel-resistant subline HLaC79Clonel as well as primary mucosal keratinocytes to increasing concentrations of the herbal mixture Prostaprotect, which has a similar formulation as PC-Spes, as well as its single herbal components Dendranthema morifolium, Ganoderma lucidium, Glycyrrhiza glabra, Isatis indigotica, Panax pseudoginseng, Rabdosia rubescens, Scutellaria baicalensis and Pygeum africanum. Growth inhibition was measured using the MTT assay. Expression of P-glycoprotein (P-GP), multidrug resistance protein-1 (MRP-1), multidrug resistance protein-2 (MRP-2), breast cancer resistance protein (BCRP) and androgen receptor (AR) were examined by western blot analysis. Pygeum africanum extract clearly turned out as the main cytotoxic component of the Prostaprotect prescription mixture, and initated apoptosis in sensitive cell lines. All other extracts had only minor toxic effects. Western blot analysis revealed increased expression of P-GP in HLaC79-Clonel cells, while HLaC79 and FADU cells were negative. All three cell lines were negative for MRP-1 and BCRP but positive for MRP-2. HLaC79 and its descendant HLaC79-Clonel both expressed $\mathrm{AR}$, as verified by western blotting and immunofluorescence staining. Primary mucosal keratinocytes were negative for all multidrug resistance markers as well as for AR. Growth inhibition rates of the single herbal extracts were compared with previously published results in prostate carcinoma cell lines. The relationship between expression levels of AR and multi-
\end{abstract}

Correspondence to: Dr Marianne Schmidt, Department of Otorhinolaryngology, University of Wuerzburg, Josef-SchneiderStrasse 11, D-97080 Würzburg, Germany

E-mail: marianne.schmidt@klinik.uni-wuerzburg.de

Key words: PC-Spes, cancer, carcinoma, head and neck, Paclitaxel, apoptosis, herbal drug drug resistance markers in relation to the measured toxicity of herbal extracts in our head and neck cancer cell system is critically discussed.

\section{Introduction}

PC-Spes is a herbal mixture containing extracts of the herbs Dendranthema morifolium, Ganoderma lucidium, Glycyrrhiza glabra, Isatis indigotica, Panax pseudo-ginseng, Rabdosia rubescens, Scutellaria baicalensis and Serenoa repens. It has been used for a long time by prostate cancer patients as an alternative and/or subsidiary treatment of prostate cancer. Herbal therapy in the treatment of benign prostatic hyperplasia as well as malignant diseases has increased during the last years, especially in the US (2) and there are a variety of clinical studies about the efficiency of PC-Spes chemotherapy in prostate cancer (3-5). In 2002, PC-Spes was recalled and withdrawn from the US market because certain batches were contaminated with prescription drugs. In the Netherlands, PC-Spes was available till 2010. Previously, a growth inhibiting effect of PC-Spes on head and neck carcinoma cell lines and primary mucosal keratinocytes has been shown. This effect occurred consistently through all cell lines tested, even in Paclitaxel-resistant cells (1). Since 2010 PC-Spes is no longer commercially available on the European market. The succeeding herbal remedy called Prospectan is available solely as tablets making it difficult to use for in vitro experiments.

Prostaprotect is available in Germany only as a personal prescription formula, due to the strict German regulation of nutritional supplements. At present there is still a discrepancy between unique admission requirements in the $\mathrm{EU}$ and the single European countries. In contrast to PC-Spes, Serenoa repens was replaced in this formulation by an extract of Pygeum africanum, a popular phytotherapeutic preparation, used in Europe and USA to alleviate the symptoms of prostatic hyperplasia (reviewed in ref. 6). Pygeum africanum is also available as Tadenan ${ }^{\mathrm{TM}}$ capsules. It is sold as a dietary supplement, but as well as other supplements, it is available only in some European countries such as France and Italy. A variety of active substances such as $\beta$-sitosterol (7), N-docosanol (8), artraric acid or N-butylbenzene-sulfonamide (NBBS) (reviewed in ref. 9) have been isolated from Pygeum bark extracts, most of them are growth inhibiting for prostate carcinoma cells and 
mediate their effects via interaction with the intracellular androgen receptor (AR).

The antineoplastic drug Paclitaxel is a natural occurring diterpenoid, isolated from the pacific yew (Taxus brevifolia) and is used as a chemotherapeutic agent for the treatment of head and neck cancer patients either alone or in combination therapy with other cytotoxic agents or radiotherapy. The therapeutic effect of Paclitaxel was tested in several studies and proved to be active in patients with squamous cell carcinoma of the head and neck. Response rates varied from 20 to $40 \%$ (reviewed in ref. 10).

We established a Paclitaxel resistant clonal subline of the larynx carcinoma cell line HLaC79, (HLaC79-Clone1) and tested the growth inhibitory/cytotoxic effects of Prostaprotect, and of single herbal ingredients on proliferation of FADU, HLaC79 and HLaC79-Clone1 cell lines and on primary mucosal keratinocytes.

In carcinomas in situ and tumour cell lines, multidrug resistance is often associated with overexpression of ATP-binding cassette transporter proteins (ABC proteins). ABC proteins that confer drug resistance include P-glycoprotein (P-GP) and the multidrug resistance associated proteins 1 and 2 (MRP-1, MRP-2) as well as breast cancer resistance protein (BCRP). The expression rates of these multidrug resistance mediating proteins by western blot were analyzed. Since PC-Spes and Pygeum africanum, both are growth inhibiting for prostate carcinoma cells, partially exert their effects via interaction with the AR, we determined expression levels of AR in the cell lines and primary cells used in our study.

Results were compared with previous studies concerning PC-Spes and single components of it. Results are critically discussed with respect to convergent observations made in prostate and head and neck cancer cells.

\section{Materials and methods}

Cell lines and cell culture. The head and neck squamous carcinoma cell line HLaC79 was established from a lymph node metastase of a laryngeal squamous cell carcinoma (11). The cell line was grown with RPMI-1640 medium (Seromed, Munich, Germany), supplemented with $10 \%$ fetal calf serum (FCS). HLaC79 cells were cultured in the presence of $10 \mathrm{nM}$ Paclitaxel and a resistant clone was isolated by selective trypsination of single clones. The permanent HLaC79 clonal cell line HLaC79Clone1 was cultured in RPMI-1640 medium, supplemented with $10 \%$ FCS and $10 \mathrm{nM}$ Paclitaxel. FADU cells were grown in RPMI-1640 medium. Mucosal keratinocytes were prepared from tonsillar tissue according to standard protocols (12). In brief mucosa was cut into small pieces, which were incubated overnight with $0.2 \%$ dispase (Sigma-Aldrich, Steinheim, Germany) in Dulbecco's modified Eagle's medium (DMEM; Seromed). The epithelium was separated with sterile forceps and digested with $0.1 \%$ trypsin (Seromed) for $20 \mathrm{~min}$ at $37^{\circ} \mathrm{C}$. Residual trypsin was inactivated by addition of FCS. Mucosal keratinocytes were collected by centrifugation and cultured in defined keratinocyte serum-free medium (Keratinocyte-SFM; Invitrogen; Karlsruhe, Germany).

Herbal plant extracts/Paclitaxel/PC-Spes. Prostaprotect capsules (not commercially available) and its single herbal

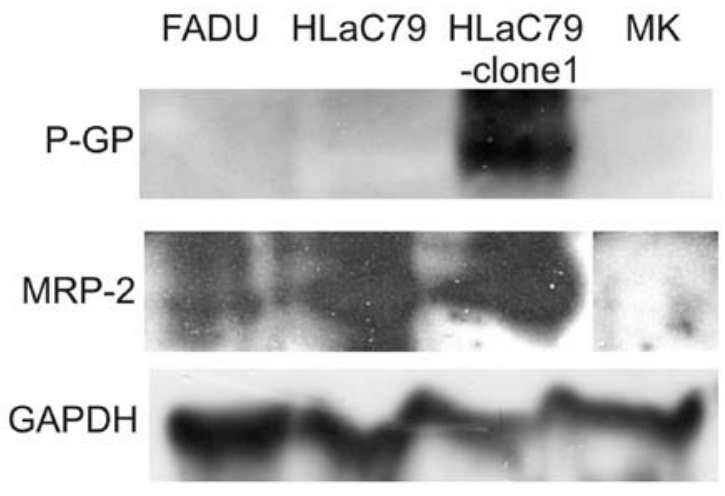

Figure 1. Western blot analysis of total cell lysates of FADU, HLaC79, HLaC79-Clone1, and mucosal keratinocytes (MK). Multidrug resistance protein-2 (MRP-2) and P-glycoprotein (P-GP), loading control GAPDH.

ingredients were provided by Burg-Apotheke Koenigstein (Koenigstein, Germany). All capsules and extracts used for these experiments originated from one single batch. The plant extracts or capsules mixtures were extracted in ethanol at concentrations applied in Prostaprotect prescriptions, at $40 \mathrm{mg} / \mathrm{ml}$ (Pygeum africanum: $50 \mathrm{mg} / \mathrm{ml}$ ). 10 capsules were dissolved in $10 \mathrm{ml}$ ethanol and incubated for $1 \mathrm{~h}$ at $37^{\circ} \mathrm{C}$. Insoluble particles were removed by low-speed centrifugation and filtration through a $22-\mu \mathrm{m}$ filter. Aliquots were stored at $-20^{\circ} \mathrm{C}$. In addition aqueous solutions of Prostaprotect and the plant extracts were prepared by dissolving ingredients in serum-free RPMI medium. Insoluble particles were removed by centrifugation. Paclitaxel was purchased from Teva GmbH (Radebeul, Germany).

Cell viability and proliferation assay. Cells were seeded at 5000 cells/well in 96-well plates. They were treated with increasing concentrations of Paclitaxel (10-200 nM) Prostaprotect $(2-10 \mu \mathrm{l} / \mathrm{ml})$ or herbal extracts $(0.2-10 \mu \mathrm{l} / \mathrm{ml})$ in RPMI medium for $24 \mathrm{~h}$. Controls were kept in medium supplemented with $10 \mu \mathrm{l} / \mathrm{ml} \mathrm{EtOH}$ for the ethanolic extract analysis without drugs. Cell proliferation was measured after $48 \mathrm{~h}$ by replacing the culture medium with medium containing $1 \mathrm{mg} / \mathrm{ml}$ MTT. After $4 \mathrm{~h}$ of incubation, MTT-staining solution was replaced by isopropanol and cells were incubated at $37^{\circ} \mathrm{C}$ for $45 \mathrm{~min}$. The colour conversion of MTT to a blue formazon dye was measured with an ELISA reader at a wavelength of $570 \mathrm{~nm}$. The amount of formazan dye is in direct proportion to the number of metabolically active cells in the culture. Single extracts growth curves were established in triplicate, the mean growth curves were standardized to the percentage of surviving cells, whereas the control cells were set at $100 \%$.

FACS analysis with Annexin $V$ antibodies. FACS analysis was performed using the Annexin V-APC kit of BD Pharmingen (BD Biosciences, Heidelberg, Germany) according to the kit manual. In brief, cells treated with $2 \mu \mathrm{l} / \mathrm{ml}$ Pygeum africanum extract for $24 \mathrm{~h}$, were harvested and washed twice with cold PBS. Cells were then resuspended in $1 \mathrm{X}$ binding buffer $(0.1 \mathrm{M}$ Hepes, $\mathrm{pH} 7.4,1.4 \mathrm{M} \mathrm{NaCl}, 25 \mathrm{mM} \mathrm{CaCl}_{2}$ ) at a concentration of $1 \times 10^{6}$ cells $/ \mathrm{ml}$. To $100 \mu \mathrm{l}$ of this cell suspension $5 \mu \mathrm{l}$ Annexin V-APC and $5 \mu 1$ 7-Amino-actinomycin D (7-AAD; included in the kit) were added and incubated for $15 \mathrm{~min}$ in the dark. 

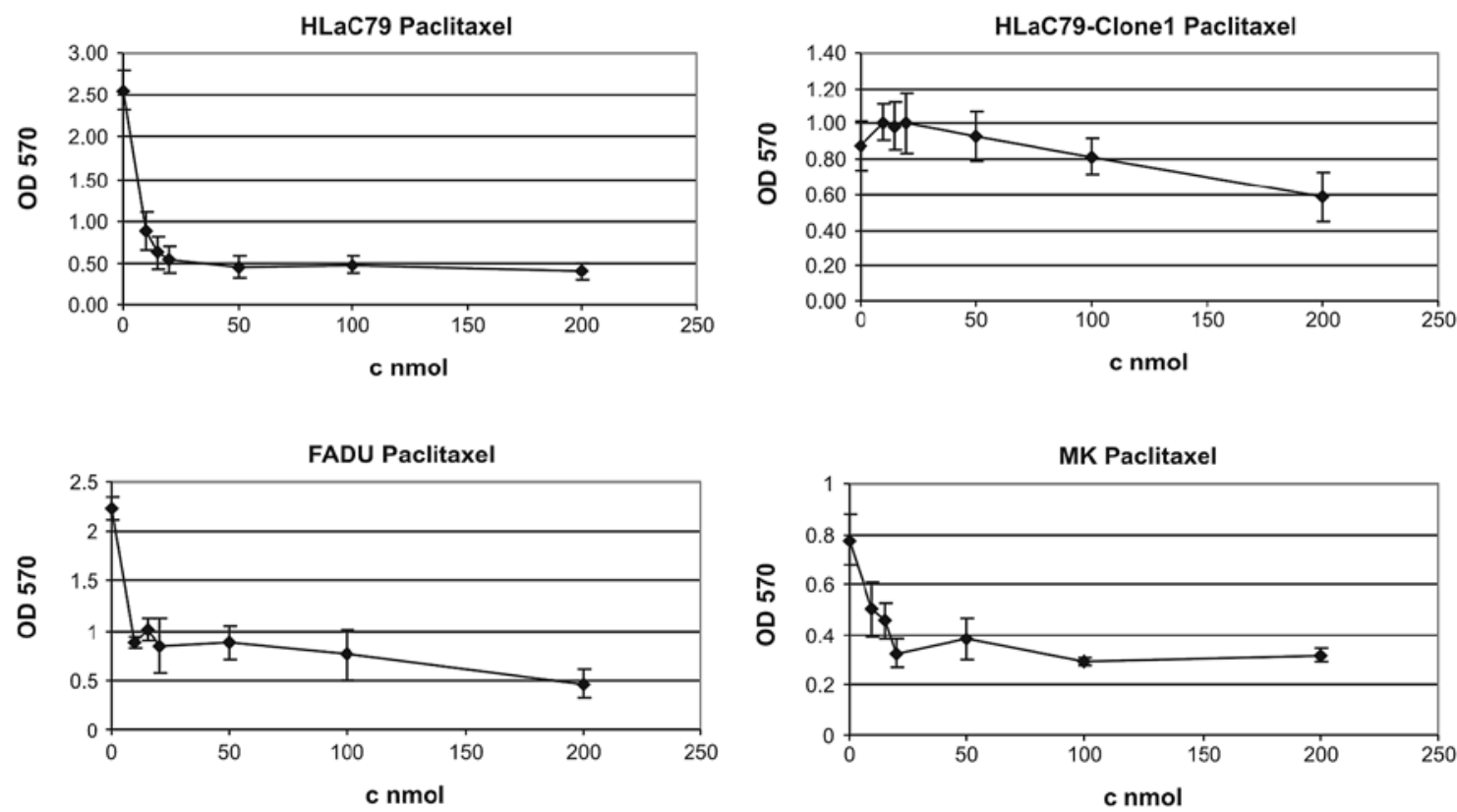

Figure 2. Treatment of cell lines/primary keratinocytes with increasing concentrations of Paclitaxel. Cell viability was measured by the colour conversion of MTT to a blue formazan at $570 \mathrm{~nm}$. Shown are the data of a representative experiment in triplicate.

Then $400 \mu \mathrm{l}$ of $1 \mathrm{X}$ binding buffer was added. Within $1 \mathrm{~h}$ FACS analysis was performed at an excitation wavelength of $650 \mathrm{~nm}$.

Western blot analysis. For western blot analysis, cells were harvested by scraping off, and dissolved in RIPA (PBS, containing $1 \%$ NP40, $0.5 \%$ sodium deoxycholate, $0.1 \%$ SDS), supplemented with $10 \mu \mathrm{g} / \mathrm{ml}$ phenylmethanesulfonyl fluoride (PMSF). Alternative crude membrane fractions (13) were used for blotting. Protein content was determined according to the method of Lowry (14). Equal amounts of total protein lysates were loaded on $10 \%$ SDS-polyacrylamide gels and run at a constant current of $20 \mathrm{~mA}$. Gels were blotted onto nitrocellulose membranes according to the semidry method of Kyhse-Andersen (15). Blots were blocked for $1 \mathrm{~h}$ with TBST (10 mM Tris, $150 \mathrm{mM} \mathrm{NaCl,} \mathrm{0.05 \%} \mathrm{Tween-20,} \mathrm{pH} \mathrm{8.0),}$ containing 5\% non-fat dry milk. For detection of AR and multidrug resistance-mediating proteins the following antibodies were used: P-GP: Calbiochem clone C219, supplied by MerckMillipore, Darmstadt, Germany; Clone F4 (Sigma-Adrich); MRP-1: Santa Cruz Biotechnology (Heidelberg, Germany); MRP-2: Santa Cruz Biotechnology; BCRP: Alexis, supplied by Enzo Life Sciences (Loerrach, Germany); AR: Cell Signaling, supplied by Merck-Millipore; GAPDH: Chemicon, supplied by Merck-Millipore.

Primary antibodies were incubated overnight at $4^{\circ} \mathrm{C}$, after washing 3 times with TBST, cells were incubated with corresponding secondary antibodies, coupled to horseradish peroxidase for $1 \mathrm{~h}$. After washing once again, detection of bound antibody conjugates was performed with the enhanced chemiluminescence system (ECL, Amersham Biosciences, Freiburg, Germany), according to the manufacturer's protocol.

Indirect immunofluorescence. Cells were grown on chamberslides. Slides were fixed with $4 \%$ formaldehyde in phosphate. Buffered saline (PBS; $137 \mathrm{mM} \mathrm{NaCl}, 2.7 \mathrm{mM} \mathrm{KCl}, 10 \mathrm{mM}$
$\mathrm{Na}_{2} \mathrm{HPO}_{4} \cdot 2 \mathrm{H}_{2} \mathrm{O}, 2 \mathrm{mM} \mathrm{KH} \mathrm{PO}_{4}, \mathrm{pH}$ 7.4) for 15 min. After washing three times with PBS the fixed cells were incubated with anti-androgen receptor antibody (Cell Signaling, Darmstadt, Germany) for $1 \mathrm{~h}$. After washing three times with PBS, cells were incubated with a secondary goat anti-rabbit antibody coupled to Alexafluor 488 (Invitrogen) for $1 \mathrm{~h}$. After washing once again, cell slides were mounted with anti-fade mounting medium (250 mg DABCO [1,4-diazabicyclo(2,2,2)octan] in 90\% glycerol, buffered with PBS).

\section{Results}

Expression analysis of drug resistance proteins $(P-G P$, $M R P-1, M R P-2$ and BCRP). Expression of P-GP, MRP-1/2 and BCRP was tested by western blot analysis of whole cell lysates. While P-GP was clearly expressed in the Paclitaxelresistant HLaC79-clone-1 subline (Fig. 1), HLaC79, mucosal keratinocytes as well as in FADU cells did not express P-GP. MRP-2 was detectable in all three cell lines, with HLaC79 and its Paclitaxel resistant Clone at a similar high level. Mucosal keratinocytes were negative for both chemoresistance markers. For MRP-1 and BCRP no signal in any cell lysate or membrane fraction was obtained.

Cell proliferation and viability assay. For evaluation of cytotoxicity/growth inhibition we exposed cell lines and primary keratinocytes to increasing concentrations of the diluent ethanol, Paclitaxel, Prostaprotect and herbal extracts for $24 \mathrm{~h}$.

Incubation of cells with EtOH exerted only minor cytotoxic effects (data not shown). In order to exclude possible cytotoxic effects of the diluent, the highest concentration of $10 \mu \mathrm{l} / \mathrm{ml} \mathrm{EtOH}$ was generally added. Each substance was measured in three separate experiments in 12 wells. Results were expressed in relation to untreated control cells (set at $100 \%$ survival rate). 

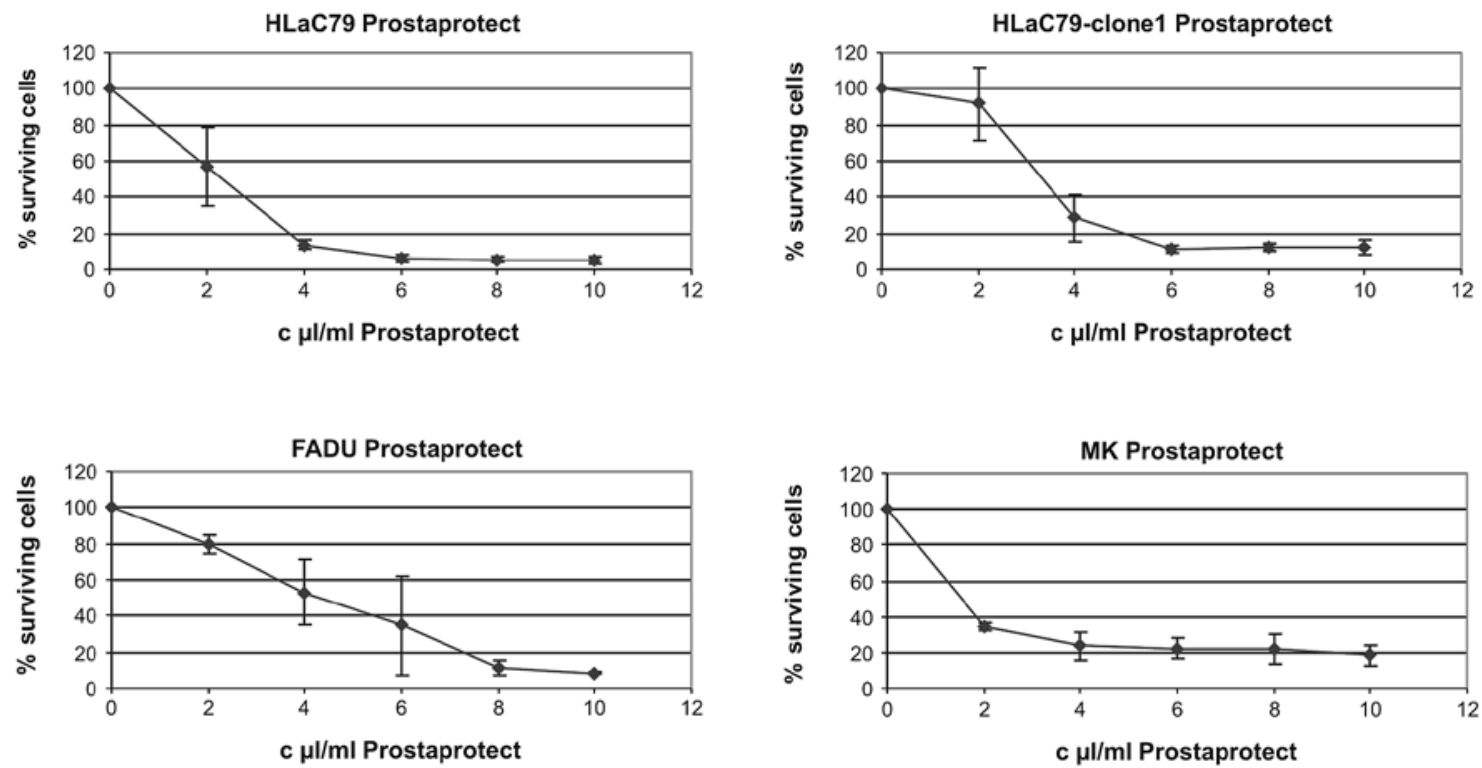

Figure 3. Treatment of cell lines/primary keratinocytes with increasing concentrations of Prostaprotect. The \% surviving cells were calculated as $\%$ of the untreated control cells. Shown are the data $( \pm$ SD) of 3 independent experiments.

Paclitaxel and prostaprotect. The cell lines and primary cells were treated with increasing concentrations of Paclitaxel (0-200 nm). After $48 \mathrm{~h}$ of incubation cell viability and cytotoxicity of the used drugs were measured with the MTT assay. Paclitaxel suppressed the growth of HLaC79 cells significantly at the low dose of $10 \mathrm{nmol}$ (Fig. 2, one of at least three independent measurements for each cell type is displayed). Cell viability decreased on average to $13.63 \%$ at $200 \mathrm{nmol}$ Paclitaxel (untreated controls set as $100 \%$ survival) in HLaC79 cells and to $20.85 \%$ in FADU cells. HLaC79-Clone1 cells as well as slowly proliferating primary mucosal keratinocytes in contrast showed only weak growth inhibition up to concentrations of 200 nM Paclitaxel (mean growth inhibition: keratinocytes 46.41\%. HLaC79-Clone1 $52.54 \%$ at $200 \mathrm{~nm}$ ). In case of highly proliferative HLaC79-Clonel cells this can be explained by up-regulated expression of P-GP (Fig. 1).

Prostaprotect proved to be strongly toxic on all cell types (Fig. 3). The highest concentration of $10 \mu \mathrm{l}$ extract $/ \mathrm{ml}$ culture medium dropped proliferation down to $5.12 \%$ in HLaC79 cells and to $14.44 \%$ in mucosal keratinocytes. In HLaC79-Clone1 cultures $12.09 \%$ cells survived after $10 \mu \mathrm{l} / \mathrm{ml}$ prostaprotect application. In FADU cells this treatment decreased proliferation to $8.52 \%$ of control cells.

Single plant extracts. Growth inhibiting properties of single herbal ingredients of Prostaprotect were tested using extract concentrations adapted to those used in the capsules. Growth curves in Fig. 4 were fitted by setting OD570 values of untreated control cells as $100 \%$ survival, which allows a direct comparison of individual extract concentrations in one diagram. Growth inhibition rates in percent of control cells at the highest extract concentration of $10 \mu \mathrm{l} / \mathrm{ml}$ for each herb are summarized in Fig. 5.

The most toxic plant extract in the Prostaprotect mixture proved to be Pygeum africanum bark extract, dropping cell survival to $16.40 \%$ (HLaC79), 14.31\% (HLaC79-Clone1), 10.42 (mucosal keratinocytes) and $42.01 \%$ (FADU; Fig. 5) at $10 \mu \mathrm{l} / \mathrm{ml}$.
Primary mucosal keratinocytes proved to be selectively sensitive towards high concentrations of Panax ginseng and Ganoderma lucidum extracts $(56.32 \%$ cell survival for Ganoderma lucidum and $46.99 \%$ cell survival for Panax ginseng at $10 \mu \mathrm{l} / \mathrm{ml}$ applied extract concentration; Figs. 4 and 5).

We observed a remarkable growth stimulation at lower concentrations $(2-6 \mu \mathrm{l} / \mathrm{ml})$ of Glycyrrhiza glabra extract in the carcinoma cell lines, but not in primary mucosa cells (Fig. 4). It has to be pointed out, however, that the concentration of licorice extract used in these experiments is $>10$-fold higher than the concentration used in PC-Spes $(40 \mathrm{mg} / \mathrm{ml}$ vs. $3.2 \mathrm{mg} / \mathrm{ml}$ in PC-Spes). Aqueous solutions of herbal extracts revealed no acute cytotoxicity on cell cultures, even at high concentrations (data not shown).

Comparison of our experimental design with previously published Pygeum studies revealed a wide variation of extract concentrations used for in vitro experiments, ranging from $10 \mu \mathrm{g} / \mathrm{ml}$ (16) to $750 \mu \mathrm{g} / \mathrm{ml}$ culture medium (7). According to the given formulation in Prostaprotect, we applied concentrations between 100 and $500 \mu \mathrm{g} / \mathrm{ml}$ Pygeum extract for treatment of cell cultures. To cover the different concentrations used in literature so far, we tested Pygeum africanum extract at lower concentrations from $10-50 \mu \mathrm{g} / \mathrm{ml}$ culture medium. Results are displayed in Fig. 6. At low concentrations up to $1 \mu \mathrm{l} / \mathrm{ml}$ (50 $\mu \mathrm{g} / \mathrm{ml})$ Pygeum africanum extract exerted only a weak growth inhibition throughout carcinoma cell lines and primary mucosal keratinocytes.

Expression of $A R$. To reveal an eventual association between AR expression and toxicity of Pygeum africanum extract AR expression was analyzed by western blotting and immunofluorescence staining. HLaC79 and HLaC79-Clone1 both showed positive reaction with AR-antibodies. Expression of AR appeared weak in comparison to cell lysates of the prostatic carcinoma cell line LNCaP, used as a positive control. FADU cells and primary keratinocytes did not express AR (Fig. 7). 

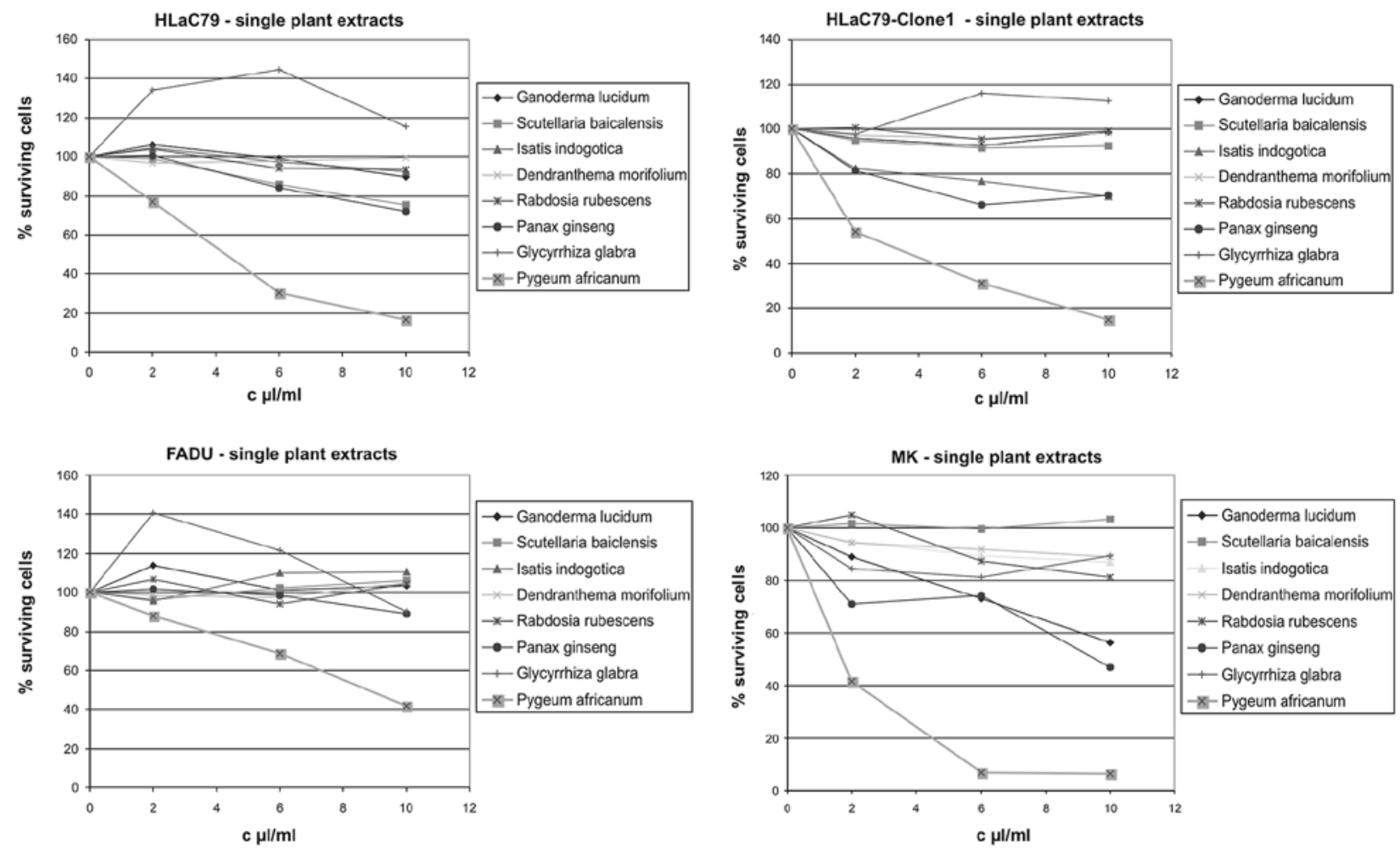

Figure 4. Treatment of cell lines/primary keratinocytes with increasing concentrations of single plant extracts in $\mu 1 / \mathrm{ml}$; untreated controls set as $100 \%$ survival and $\mathrm{c}$, concentration of the plant extracts in $\mu \mathrm{l} / \mathrm{ml}$.
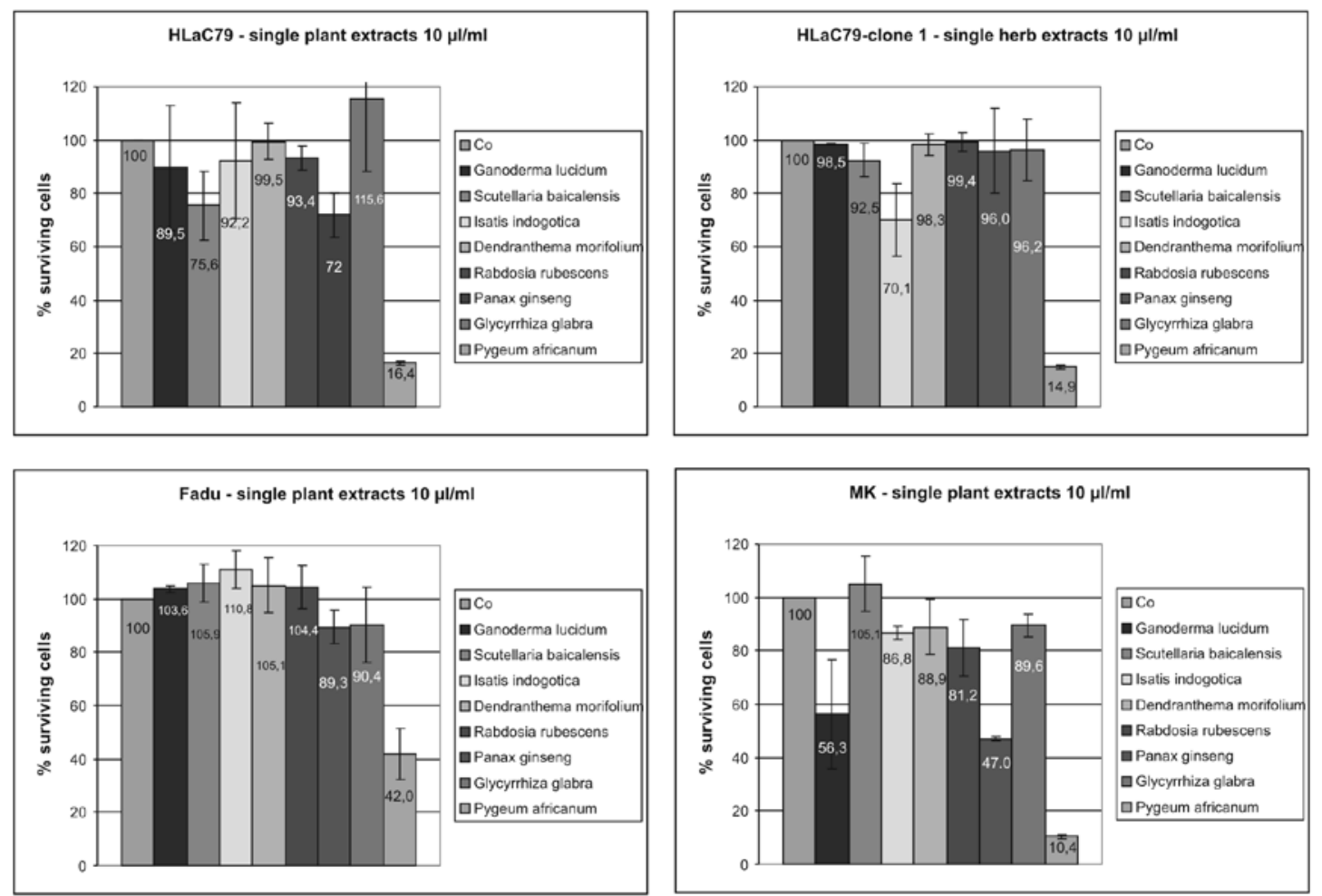

Figure 5. Influence of the highest concentration of the individual herbal extracts on the \% surviving cells (untreated control cells set as $100 \%$ survival).

In order to exclude clonal or aberrant expression of AR in our cell lines we performed immunofluorescence staining. Antibody staining showed a weak but specific nuclear staining throughout the population of HLaC79 and HLaC79-Clone1 cells (HLaC79 Fig. 8). FADU cells and mucosal keratinocytes were negative for AR staining. 


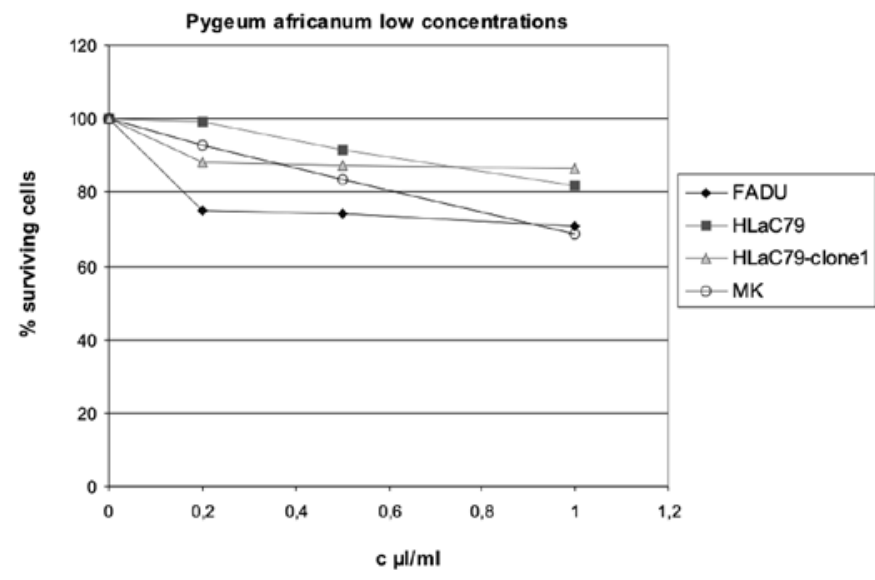

Figure 6. Influence of lower concentrations of Pygeum africanum extract (from $0-50 \mu \mathrm{g} / \mathrm{ml}$ corresponding to $0-1 \mu \mathrm{l} / \mathrm{ml}$ on the $\%$ surviving cells in head and neck cancer cell lines and primary mucosal keratinocytes (untreated control cells set as $100 \%$ survival).

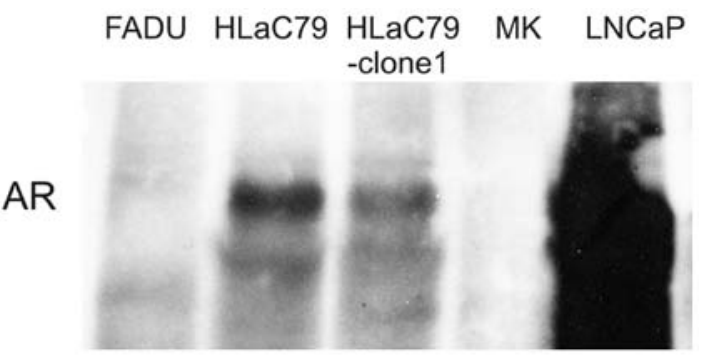

Figure 7. Western blot analysis of total lysates of FADU, HLaC79, HLaC79Clone1, and mucosal keratinocytes (MK). AR, androgen receptor, as a positive control LNCaP cell lysates were applied to the gel.

Apoptosis - FACS analysis with Annexin $V$ antibodies. FACS analysis with the Annexin V-APC kit was carried out for Pygeum africanum, the herbal extract acting most toxic in our cell lines and primary cells. Pygeum africanum extract significantly increased apoptotic cell fractions after $24 \mathrm{~h}$ incubation in both the Paclitaxel-sensitive cell line HLaC79 and the Paclitaxel-resistant cell line HLaC79-Clone1 (Fig. 9: HLaC79Clone1 $14.7 \%$ apoptotic fraction; HLaC79 56.4\%). HLaC79 and HLaC79-Clonel differed in sensitivity, which might be caused by the increased detoxification capacity of HLaC79-Clone1 cells. In FADU cells, however, a low concentration of Pygeum extract was not able to significantly trigger apoptosis $(1.2 \%$; Fig. 9).

\section{Discussion}

In advanced laryngeal and hypopharyngeal cancer the chemotherapeutic agent Paclitaxel is commonly used for chemotherapy in order to preserve laryngeal and/or pharyngeal structures. Although Paclitaxel generally seems to be a powerful agent, it failed to reach a local-regional tumour control in $12 \%$ of patients according to a previously published study (10). Chemotherapeutic failure may be related either to inherited resistance against the drug or/and the acquirement of resistance during the therapy. Drug resistance is mostly a multifactorial procedure, in the case of Paclitaxel several mechanisms have
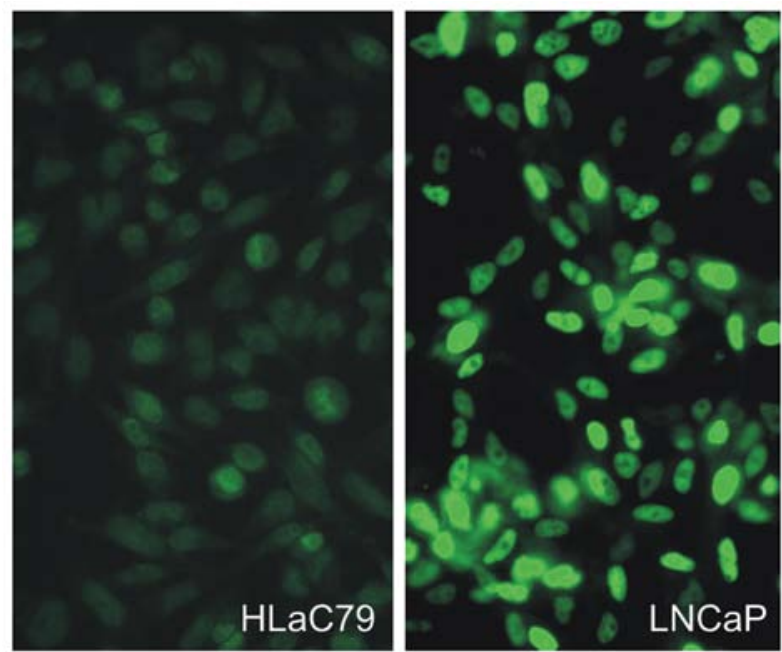

Figure 8. Photomicrograph of immunofluorescence staining of AR in HLaC79 cells. As positive control prostatic LNCaP cells were used (right panel).

been described. One mechanism is the overexpression of multidrug resistance proteins, such as P-glycoprotein (P-GP) (coded by the multidrug resistance gene 1, MDR-1, P-GP), multidrug resistance-associated proteins (such as MRP1 and MRP2) or breast cancer resistance protein (BCRP). P-GP overexpression in Paclitaxel-resistant HLaC79-Clonel cells was confirmed.

Considering single components combined in the Prostaprotect prescription, we observed a growth stimulating effect of licorice extract in head and neck cancer cell lines. In contrast, Hsieh et al (17) observed a clear anti-mitogenic effect of Glycyrrhiza extract on prostate carcinoma cell lines. The Glycyrrhiza extract used in our study was over 10-fold higher concentrated than those used by Hsieh et al (17). Kimura et al (18) described a growth stimulating effect of Glycyrrhizin and some analogues on primary hepatocytes acting via binding to EGF receptors. Molarities of the single substances used in the above mentioned study can't be related to our extracts, but tyrosin phosphorylation of EGF receptors, which are overexpressed in $90 \%$ of head and neck carcinomas (19) might also occur in head and neck cancer cell lines.

In the Prostaprotect mixture Pygeum africanum turned out to be the major toxic component. Pygeum africanum, also available as Tadenan capsules is sold as a dietary supplement, used to treat prostatic hyperplasia, has been shown to hold a variety of active substances such as $\beta$-sitosterol (7), $\mathrm{N}$-docosanol (8), artraric acid or N-butylbenzene-sulfonamide (NBBS) (reviewed in ref. 9). All these substances have been isolated from Pygeum bark extracts, most of them are growth inhibiting for prostate carcinoma cells and mediate their effects via interaction with the intracellular androgen receptor (AR). Shenouda et al (7) showed a growth inhibiting effect of Pygeum extract on AR-dependent $\mathrm{LNCaP}$ as well as AR-independent growing PC3 prostate carcinoma cell lines. However, they did not observe any toxic effect on AR-negative $\mathrm{CaCO}_{2}$ colon cancer cells at very high concentrations and concluded a clear action of Pygeum extract via the AR.

The role of $\mathrm{AR}$ in the development of laryngeal cancer is still controversial. A number of publications are available concerning AR expression in head and neck carcinoma tissue, 

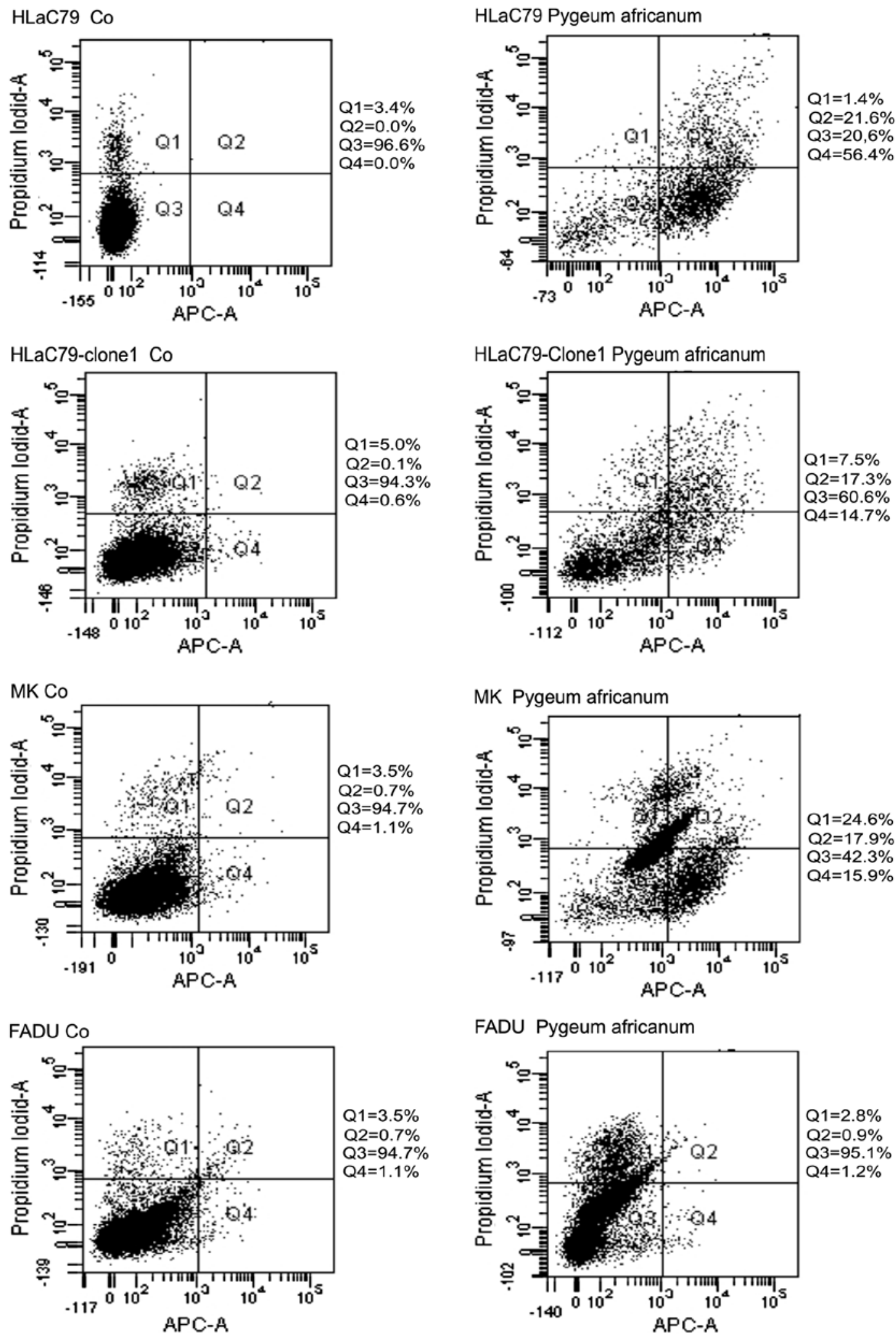

Figure 9. FACS analysis of cultured cells with the Annexin V-APC kit after $24 \mathrm{~h}$ of incubation with Pygeum africanum extract $(2 \mu 1 / \mathrm{ml})$. Cells $(10,000)$ were measured in each single experiment. Q4 shows the percentage of the apoptotic cell fraction.

expression rates ranging between $0 \%(20)$ and $68.3 \%$ (21). Even in normal adjacent tissue no common expression rates for AR are available. While Chen et al (21) observed $0 \%$ AR expression in normal mucosa, Nehse et al (22) report even higher AR expression in mucosa than in tumour tissue. These controversial results are at least partially caused by the different detection methods used, such as in situ hybridization, or RT-PCR for measuring mRNA transcription, immunohistochemistry and receptor assays for determination of protein expression or activity. 
In the present study AR expression was examined on protein level, using western blot detection and immunofluorescence staining and revealed a weak AR expression signal in $\mathrm{HLaC} 79$ and HLaC79-Clone 1 cells. Nevertheless we observed strong toxicity of Pygeum extract on all cell lines, AR-positive or -negative, when used in concentrations adapted to Prostaprotect concentrations. Using lower concentrations of Pygeum extract gained a closer look on cellular changes. All three cell lines survived quantitatively. There was no striking difference between AR-positive and AR-negative cell lines in the MTT assay caused by treatment with Pygeum extract, but apoptosis was more pronounced in AR-positive $\mathrm{HLaC} 79$ and HLaC79-Clone1 cells. On the other hand there is a tremendous difference in Pygeum sensitivity between vulnerable HLaC79 cells and p-GP expressing HLaC79-Clonel cells. Furthermore, we observed that Pygeum extract at low doses massively triggered apoptosis in primary keratinocytes, although these cells were clearly AR-negative.

The discrepancy to previous studies is probably based on two major problems: first the diversity of extracts used for experiments is a tremendous black box. There is no standard formulation available, except Tadenan capsules, which are no longer available in most European countries presumably because of art protection constraints (Phytolab Inc., personal communication). Besides Tadenan is not useful for in vitro investigations because peanut oil is the major solvent in the capsules. A variety of undefined Pygeum capsules, powders and tablets circulating at the European market are sold via internet shops. Extracts and concentrations used for investigations are not comparable. The second problem is the lack of a holistic consideration in studies. Most studies have concentrated on cause and effect of drugs applied to cells with one certain aspect focused on, for example the role of the AR. Considering the system of a cell in its entirety, however, includes also a view to the capacity of drug detoxification, growth rates, genetic constellation etc. How tightly the diverse cellular mechanisms are linked has been shown for example by Fedoruk et al (23) who demonstrated, that P-GP increases the efflux of dihydrotestosterone (DHT) from cells and is able to reduce androgen responsive gene activity in prostate cancer cells. This cross-functional features are especially important, when herbal mixtures such as PC-Spes are used for studies, with components influencing different cellular functions such as AR expression (17) or P-GP activity and/or expression (reviewed in ref. 24).

All other components used for formulation of the Prostaprotect mixture exerted only minor cytotoxicity on cell lines and primary cells. Solely the extract of Panax ginseng inhibited the growth of mucosal keratinocytes quantitatively. This is in contrast to the study of Hsieh et al (17), who described strong toxic effects of Glycyrrhiza, Isatis, Scutellaria, Dendranthema, Rabdosia, Ganoderma and Panax on prostate carcinoma cell lines even at the concentration of $5 \mu \mathrm{l} / \mathrm{ml}$ medium. One reason for the discrepancy between the studies might be the different cellular systems but again, the problem of diversity of extracts used for treatment of cells exists.

In summary, we demonstrated that individual herbs such as Pygeum africanum extract used for treatment of prostatic diseases might also achieve growth inhibition in head and neck cancer cells, even if these cells are resistant to Paclitaxel. The growth inhibiting effect seems to be affected both by detoxification capacity of cells, as well as the expression of AR. The role of the AR in development and course of head and neck cancer remains to be revealed. Furthermore, it should be reconsidered as to which combinations of natural compounds make sense for practical use. Nevertheless, it seems possible, that combinations of purified herbal compounds may be used in combination with conventional anticancer therapy, to achieve synergistic activities.

\section{Acknowledgements}

We are grateful to Dr Jürgen Arnhold for providing information about Prostaprotect prescription and composition. We would like to thank Dr Petrus Tas for critical reading of the manuscript.

\section{References}

1. Schmidt M, Polednik C, Gruensfelder P, Roller J and Hagen R: The effects of PC-Spes on chemosensitive and chemoresistant head and neck cancer cells and primary mucosal keratinocytes. Oncol Rep 21: 1297-1305, 2009.

2. DiPaola RS, Zhang H, Lambert GH, Meeker R, Licitra E, Rafi MM, Zhu BT, Spaulding H, Goodin S, Toledano MB, Hait WN and Gallo MA: Clinical and biologic activity of an estrogenic herbal combination (PC-Spes) in prostate cancer. N Engl J Med 339: 785-791, 1998.

3. De la Taille A, Buttyan R, Hayek O, Bagiella E, Shabsigh A, Burchardt M, Burchardt T, Chopin DK and Katz AE: Herbal therapy PC-Spes: in vitro effects and evaluation of its efficacy in 69 patients with prostate cancer. J Urol 164: 1229-1234, 2000.

4. Moyad MA, Pienta KJ and Montie JE: Use of PC-Spes, a commercially available supplement for prostate cancer, in a patient with hormone-naive disease. Urology 54: 319-324, 1999.

5. Small EJ, Frohlich MW, Bok R, Shinohara K, Grossfeld G, Rozenblat Z, Kelly WK, Corry M and Reese DM: Prospective trial of the herbal supplement PC-Spes in patients with progressive prostate cancer. J Clin Oncol 18: 3595-3603, 2000.

6. Dedhia RC and McVary KT: Phytotherapy for lower urinary tract symptoms secondary to benign prostatic hyperplasia. J Urol 179: 2119-2125, 2008.

7. Shenouda NS, Sakla MS, Newton LG, et al: Phytosterol Pygeum africanum regulates prostate cancer in vitro and in vivo. Endocrine 31: 72-81, 2007.

8. Pierini N, Citti F, Di Marzio S, Pozzato C and Quercia V: Identification and determination of $\mathrm{N}$-docosanol in the bark extract of Pygeum africanum and in patent medicines containing it. Boll Chim Farm 121: 27-34, 1982 (In Italian).

9. Roell D and Baniahmad A: The natural compounds atraric acid and N-butylbenzene-sulfonamide as antagonists of the human androgen receptor and inhibitors of prostate cancer cell growth. Mol Cell Endocrinol 332: 1-8, 2011.

10. Pfreundner L, Hoppe F, Willner J, Preisler V, Bratengeier K, Hagen R, Helms J and Flentje M: Induction chemotherapy with paclitaxel and cisplatin and CT-based 3D radiotherapy in patients with advanced laryngeal and hypopharyngeal carcinomas - a possibility for organ preservation. Radiother Oncol 68: 163-170, 2003.

11. Zenner HP, Lehner W and Herrmann IF: Establishment of carcinoma cell lines from larynx and submandibular gland. Arch Otorhinolaryngol 225: 269-277, 1979.

12. Imaizumi F, Asahina I, Moriyama T, Ishii M and Omura K: Cultured mucosal cell sheet with a double layer of keratinocytes and fibroblasts on a collagen membrane. Tissue Eng 10: 657-664, 2004.

13. Limtrakul P, Anuchapreeda S and Buddhasukh D: Modulation of human multidrug-resistance MDR-1 gene by natural curcuminoids. BMC Cancer 4: 13, 2004.

14. Lowry OH, Rosebrough NJ, Farr AL and Randall RJ: Protein measurement with the Folin phenol reagent. J Biol Chem 193: 265-275, 1951.

15. Kyhse-Andersen J: Electroblotting of multiple gels: a simple apparatus without tank for rapid transfer of proteins from polyacrylamide to nitrocellulose. J Biochem Biophys Methods 10: 203-210, 1984. 
16. Yablonsky F, Nicolas V, Riffaud JP and Bellamy F: Antiproliferative effect of Pygeum africanum extract on rat prostatic fibroblasts. J Urol 157: 2381-2387, 1997.

17. Hsieh TC and Wu JM: Mechanism of action of herbal supplement PC-SPES: elucidation of effects of individual herbs of PC-SPES on proliferation and prostate specific gene expression in androgen-dependent LNCaP cells. Int J Oncol 20: 583-588, 2002.

18. Kimura M, Inoue H, Hirabayashi K, Natsume $\mathrm{H}$ and Ogihara M: Glycyrrhizin and some analogues induce growth of primary cultured adult rat hepatocytes via epidermal growth factor receptors. Eur J Pharmacol 431: 151-161, 2001.

19. Grandis JR and Tweardy DJ: Elevated levels of transforming growth factor alpha and epidermal growth factor receptor messenger RNA are early markers of carcinogenesis in head and neck cancer. Cancer Res 53: 3579-3584, 1993.
20. Bianchini C, Pastore A, Pelucchi S, et al: Sex hormone receptor levels in laryngeal carcinoma: a comparison between protein and RNA evaluations. Eur Arch Otorhinolaryngol 265: 1089-1094, 2008.

21. Chen B, Wang J, Li W and Ji W: Expression of androgen receptor and estrogen receptor in carcinoma of larynx. Lin Chuang Er Bi Yan Hou Ke Za Zhi 20: 649-651, 2006 (In Chinese).

22. Nehse G and Tunn S: Androgen and progesterone receptors in oral carcinoma. J Craniomaxillofac Surg 22: 114-119, 1994.

23. Fedoruk MN, Gimenez-Bonafe P, Guns ES, Mayer LD and Nelson CC: P-glycoprotein increases the efflux of the androgen dihydrotestosterone and reduces androgen responsive gene activity in prostate tumor cells. Prostate 59: 77-90, 2004.

24. Izzo AA and Ernst E: Interactions between herbal medicines and prescribed drugs: a systematic review. Drugs 61: 2163-2175, 2001. 